RAINFOREST COWBOYS 
THIS PAGE INTENTIONALLY LEFT BLANK 


\section{RAINFOREST COWBOYS}

The Rise of Ranching and Cattle Culture

in Western Amazonia

JEFFREY HOELLE 
This book is a part of the Latin American and Caribbean Arts and Culture publication initiative, funded by a grant from the Andrew W. Mellon Foundation.

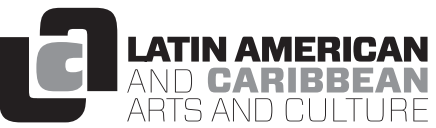

Copyright (C) 2015 by the University of Texas Press

All rights reserved

Printed in the United States of America

First edition, 2015

Requests for permission to reproduce material from this work should be sent to:

Permissions

University of Texas Press

P.O. Box 7819

Austin, TX 78713-7819

http://utpress.utexas.edu/index.php/rp-form

(2) The paper used in this book meets the minimum requirements of ANSI/ NISO Z39.48-1992 (R1997) (Permanence of Paper).

LIBRARY OF CONGRESS CATALOGING-IN-PUBLICATION DATA

Hoelle, Jeffrey, 1976-

Rainforest cowboys : the rise of ranching and cattle culture in western Amazonia / Jeffrey Hoelle. — First Edition.

pages $\mathrm{cm}$

Includes bibliographical references and index.

ISBN 978-0-292-76134-6 (cloth : alk. paper)

1. Beef cattle-Environmental aspects-Brazil-Acre. 2. Ranching-

Environmental aspects-Brazil-Acre. 3. Deforestation-Brazil-Acre.

4. Human ecology-Brazil-Acre. I. Title.

SF196.B6H64 2015

636.2'13098112-dc23

2014023106

doi:10.7560/761346 
TO MY MOTHER 
THIS PAGE INTENTIONALLY LEFT BLANK 